\title{
Täpa as an Underrated Nepali Novel (Book Review)
}

\author{
Indira Acharya Mishra, $\mathrm{PhD}^{*}$
}

Tāpa, the debut novel of Sharada Sharma, though it is the winner of Padmaśri Sāhitya Sammāna 2012, is an underrated Nepali novel. The novel forms a part of my Ph.D. Dissertation. I chose Sharma as a representative woman novelist in Nepali literature. I was impressed by the narrative techniques and characterization in the novel. The author has chosen characters from diver backgrounds to highlight the theme of humans' sufferings. The characters are portrayed as particular individuals and have unique experiences of life. Nonetheless, they all, in one way or another, suffer in their lives. To impart this message, she uses multiple narrators and handle them skillfully. So far as my reading of Nepali novels is concerned, I was dismayed by the fact that the novel has failed to gain a satisfactory readership from the readers of Nepali literature. One of the aims of my Ph.D. thesis was to analyze the narrative techniques of the selected novels. I found Sharma's skills in handling multiple narrators quite praiseworthy. She uses multiple narrators to reveal the multiple perspectives of the characters who belong to different socio-political, economic, educational, and geographical background. It shows her understanding of human psychology. Likewise, the flashback and foreshowing techniques are aptly used to relate the events that happen in different periods. The techniques provide the necessary information to the readers. In terms of characterization, also she appears skillful. Most of the characters sound authentic.

Set primarily in monasteries, and in äśramas in and around the Kathmandu Valley, some of the incidents of the novel, however, take place in India, England, and partially in Dhaka. The narrative of the novel goes back to the Rana Dynasty and deals up to the events that happened during the Maoist Insurgency of Nepal, covering more than a hundred years. However, the main plot of the novel relates to the events that occur within the fifty years of its main protagonist, Chandrika Maharani's life. The novel explores the failed marital and family lives of its protagonist. It traces the worries and tensions that she has to bear despite her economic affluence and intellectual integrity.

${ }^{*}$ Dr. Mishra is Associate Professor of English currently working at Mahendra Multiple Campus Dharan, Tribhuvan University, Nepal. 
Divided into thirteen chapters, besides the opening and the ending, the novel is narrated by various narrators from diverse socio-economic, cultural, and even political backgrounds. These various narrators, who peep into their own life using monologue, at description, and letter, reveal that despite the surface differences among people, no one is free from typical human desires. Though people try to escape the social problems, they fail. People suffer for they have different types of physical, mental, and spiritual worries and tensions, which the author names as tapa in the novel. Even the monasteries and hermitages, where people go to achieve peace and harmony through mediation, are not free from common human emotions like mutual affection, rivalry, competition, hatred, and antipathy towards each other. Because of these common human emotions, humans have to bear tāpa. Even the hermits, who have been living the spiritual life, also aspire for power and position. They, too, have the same physical and psychological desires as ordinary people living the typical social life. They are also lured by modern affluent lifestyle and have sexual attraction towards the opposite sex. Here, in her dealing with the sexual psychology of humans' Sharma comes closer to B.P Koirala. The plot of the novel is circular. It begins with the end of the novel, and goes on unfolding with the use of the flashback technique. This technique is correctly used to relate the earlier events. Six principal characters, who are the narrators of the novel, narrate their private lives and their collective lives marked by friendship, love, and betrayal. They tell their stories as they perceive them. The use of multiple narrators helps to understand the different ways of perceiving things. Besides, these homodiegetic narrators reveal the secrets of their lives. In addition to these first-person narrators, the author uses a third person omniscient narrator who narrates the incidents beyond the reach of the first-person narrators.

The beginning of the novel named "Aamukh," is narrated by the third person omniscient narrator. The all-knowing narrator describes the incidents of Sujata, an important female character of the novel, being appointed as the chief monk of the monastery by the monk Tulku Chhoden Rinpoche. The narrator reads the psychology of the senior nun: "'My Buddha daughter!' She might have kissed her with love more than fifty times. She has been too happy for the last few days." Sujata's appointment as the head of the monastery is a historical event. She is the first woman to achieve this position in the history of Buddhism in Nepal. Then, with the flashbacks techniques, and multiple narrators the novel tells how a carefree, highly educated girl from an aristocratic family has been lead to live the life of a nun. The flashbacks grab the readers' attention, though a little bit slower.

Sujata, a Master's degree holder in Philosophy from the USA, has been appointed as the chief of the monastery because of her hard work and depth of knowledge in the religion. Guru Tulku Chhoden Rinpoche confirms that among the 
female characters, she is a rear one. She has achieved the state of equilibrium and has an equal response to both pleasure and pain. She neither feels hatred nor disgust when she thinks of her mother and the army personals who had tortured her; rather, somehow she remains thankful to them because if they had not been in that way, she would not have been there. The readers become curious to know her relation with her mother and the reasons why she was tortured by the police. The all-knowing narrator also suggests that even the recluses tend to have an ego and fight for power. The story of the novel progresses with Sujata, a twenty-four-year old university graduate narrating her past. She recalls her first day in the monastery, her terrible dream in which she had been attacked by four persons in combat dress in an awful underground lane. She remembers the mechanical life that she had spent in the USA while doing her Master's, and how she decided to return to Nepal, being fed up with the American mechanical life. She expresses her dissatisfaction towards the discriminatory rules of the monastery as it has different rules for males and other rules for females. She also discloses the fact that though people in the monasteries are searching of spirituality, they fail to control their desires for material things. This fact is highlighted by ani Yanchhen's expensive getup and other anis' attraction towards her style. Sujata eavesdrops on other nuns talking about Yanchhen apparel: 'Have you seen Yanchhen's watch?' A young nun was asking to another nun while I was coming to the courtyard. / 'Was not her robe made up of silk?' / 'Bag was rather beautiful!'" Looking at the nuns watching movies, giggling and whispering to each other, Sujata wonders how "much difficult it would be for these innocent girls, clad in the maroon gown to protect themselves from the volcanic lust of life." Through Sujata the author critically analyzes the religion's futile attempts to make the inexperienced girls indifference towards the worldly pleasure.

Sujata recalls her friendship with Mukti and the whirlwind of circumstances that have changed the course of her life. She says that one night while coming from the disco, she got arrested as a suspected Maoist. Her narration reveals police brutality towards the female inmates. Sujata reports the inhumane torture given to the prisoners. She observes the pathetic condition of Maya, a Maoist cadre in the jail as she was beaten to death. She also explores the problems faced by the female inmates for the prisons do not have female friendly infrastructures. She has been menstruating and she has to wear the same underwear for more than a day.

Mukti, one of the major male characters in the novel, narrates how the Maoist war devastated the life of ordinary people. His narration reveals the suffering of poor rural people like Santosh Chaudhary who was murdered by the Maoists in the pretext of spying against them. When he recalls his daughter, Rubel Chaudhary pleading for mercy from the Maoists he is reminded about his own mother pleading the army not to kill him. He realizes that both of them belong to the same class as the war victims. The 
senseless killing of the innocent people from the state and the revolutionary group forced him to analyze the revolution's relevance. No matter who gets killed, it is the same poor parents to mourn the death of their children.

Likewise, Chandrika Maharani tells her own story from the sixth chapter onwards. Using the flashback technique, she narrates her sheltered childhood days in her parents' company in Simla, India as the great-granddaughter of Bir Shamsher Rana, the then Prime Minister of Nepal. Despite being grown up in a closed patriarchal family, Chandrika managed to go to England for higher education. Her narration exposes different types of gender-based violence experienced by women. Through the description of characters like Arbinda and Sebakram she shows the misuse of women's bodies as sexual objects that the rich can buy for their pleasure. The way Arbinda behaves reveals how women are exploited in a conjugal life under patriarchy. She was doing her Master in Gender Studies when she met Prabhakar, from Gorkha, a $\mathrm{PhD}$ scholar in Microbiology. After completing her degree, Chandrika married Prabhakar, and they returned to Nepal. The conflict appeared in their married life as Chandrika was unable to cope with the role of a lower middle-class house-wife demanded by Prabhakar's family. She finds herself reduced to the status of domestic labor. Her understanding reminds Beauvoir, who believed that "marriage trapped and stunted women's intellectual growth and freedom." As an educated gender-sensitive lady, she believes that husband and wife are equal; and the daughter-in-law is not there to work as a domestic servant. It would not be possible for her to invest all her energy in the domestic trifle. Chandrika could not adjust to this position, and when things did not get changed she divorced him and lived the life of a single parent for her daughter Sujata. Her struggle as a woman does not end here. Sujata's arrest creates a different type of tensions and worries which the mothers of grown-up daughters have. Through Chandrika's narration the readers know how the powerful men's bargain for women's bodies when the women turn to them for help. Her description of Parashar suffices this aspect. Selection of Chandrika, a gender expert, as a character to explore gender-based violence against women is an authentic one.

Her observation of Parashar reveals how women are harassed in the day to day life. Though he has been the Home Minister, the one supposed to provide safety to the citizens, he was the cause of terror. In "Kaiwalya Áśram," Chandrika shares that she had been suffering from acute depression, and to get rid of her suffering through meditation, she went to the āśram. However, she could not experience peace as she noticed that such ashrams were also not free from domestic problems and tensions. She questions the use of such training as people are forced to meditate despite being physically unfit. Chandrika acknowledges that she was sensually attracted towards the Guru; but she felt insulted by the indifferent look towards her physique. This reflects 
her psychology. Her monologue also reveals her attraction to the Guru, which was the cause of tension to Upasika, the Guru's wife.

Professor Yaman also peeps into his past. He also describes the incidents that he observed when he went to the ashram, accompanying Chandrika to meet her daughter Sujata. Similarly, "Mātā Upāsikā," narrated by Upasika, Guru Kaiwalya's wife, is an address to Chandrika. In the flashback, she tells how a daughter from a well to do family became a dancer, met the Guru, who is fifteen years older than herself, and married him on her own. She says that she had sacrificed everything for the sake of her husband Kaiwalya, but her husband after he had been appointed as the head of the ashram started being indifferent towards her. Her husband, without her consent, had started sleeping in a separate room. Upasika's narration reveals the existence of a double standards in patriarchy. The husband expects to have sex with his wife any time he likes. But in the pretext of gaining enlightenment, he disregards his wife's sexual urges. Men, in general, take it for granted that a woman does not demand means that she has no urges. But Upasika's narration proves it wrong. She argues:" "Naturally, I have both physical and psychological desires. It has been months since those desires are not satisfied by my husband. . . I I still have sexual urges." From Upasika's perspective, Sharma reveals the issues of sexuality and pleasure for women along with women's right to enjoy sex.

The last chapter, "Guru Kaiwalya," narrated by the Guru, reveals his disturbing mentality because of witty and intellectual ladies like Gargi and Chandrika. The Guru confesses despite his attempt to remain indifferent to women and sex, he has desires, and he has been provoked by the attractive women in the ashram, and despite his effort, he has been dripped. He felt guilty as he could not share this with his wife. It reveals the hierocracy of the so-called enlightened people. The Guru has not been sharing bed with his wife but he confesses that he has been unable to resist intelligent and beautiful women. Nonetheless, he admits that women are more practical than men as they do not have to make any pretext for power and position.

Besides the omniscient narrator, the six main characters take the turn to narrate the story of the novels. The use of multiple narrators helps to understand the different aspects of the same incidents. For example, the incident of Sujata's missing is narrated by Sujata herself, Chandrika and Mukti. Likewise, the Guru's feeling of Chandrika is narrated by both. Chandrika thinks that the Guru is indifferent towards her, but the Guru confesses that he finds her provoking and is unable to resist her. The relation between Upasika and the Guru is narrated by both of them from their own perspectives. The repetition of the same event/s with different narrators shows that the same events can be viewed differently depending on the belief and focus of the narrator. For example, when the Guru takes his turns, his psychological state gets revealed different through his 
confession. Until now, he has been seen as a charismatic figure, who has achieved enlightenment and has already gained control over bodily desires. But, he, too, is revealed as having physical weakness, i.e. he is not devoid of worries and tensions, though he pretends to be.

The novelist skillfully handles the multiple narrators to cover the incidents that take place across time and space. The characters are authentic and reliable. They are portrayed as unique individuals, and they have unique experiences because they are different from the mundane people. However, their suffering is universal. The way she selects characters from the various strata of society and makes them sound authentic shows the author's wider exposer to life. The vivid description of the innermost secrets of these characters reveals the novelist's sensibility towards human psychology. The use of poetic and refined language proves her command over the Nepali language. Consideerd as a whole, the novel is one of the best Nepali novels and deserves more reading from the reading public.

\section{References}

Abott, H. P. (2002). The Cambridge introduction to narrative. Cambridge UP. Astaphal, S. (2010). Tāpa upanyāsmāabhibyanjitamanawiyarāpaharū[Human Tensions Revealed in the Novel Täpa.]<http://www.pallawa.com.np>.

Bal, M. (2009). Narratology: Introduction to the theory of narrative. $3^{\text {rd }}$ ed. University of Toronto Press.

Beauvoir, de S.(1993). The Second Sex. Tran \& Ed. H. M. Parshley. David Campbell Publisher Ltd.

Belsey, C.\& Moore, J.Eds., (1998). The Feminist reader: essays in gender and the politics of literary criticism. Macmillan.

Booth, C. W. (1987). The rhetoric of fiction. $2^{\text {nd }}$ ed. Penguin Books.

Currie, G. (2010).Narratives \&narrators: A philosophy of stories. Oxford UP.

Koirala, K. (2017). Tāpamābyānjitauttaraādhunikanāribādīsoca[Post-modern feminist approach revealed in Täpa.]Garimā,31.9, 71-78.

Mishra, I. A. (2018). Dynamics of women's narratives in Nepali novels. Ph.D. dissertation, TU.

Sharma, S. (2012). Tāpa [Heat.]Sangrila Publication. 